\title{
Enantioselective metabolism of hydroxychloroquine employing rats and mice hepatic microsomes
}

\author{
Carmem Dickow Cardoso ${ }^{1 *}$, Pierina Sueli Bonato ${ }^{2}$ \\ ${ }^{I}$ Center of Life and Health Sciences, Course of Pharmaceutics, UCPel/RS, Catholic University of Pelotas \\ ${ }^{2}$ Department of Physics and Chemistry, Faculty of Pharmaceutical Sciences of Ribeirão Preto, University of São Paulo
}

\begin{abstract}
Hydroxychloroquine (HCQ) is an important chiral drug used, mainly, in the treatment of rheumatoid arthritis, systemic lupus erythematosus and malaria, and whose pharmacokinetic and pharmacodynamic properties look to be stereoselective. Respecting the pharmacokinetic properties, some previous studies indicate that the stereoselectivity could express itself in the processes of metabolism, distribution and excretion and that the stereoselective metabolism looks to be a function of the studied species. So, the in vitro metabolism of HCQ was investigated using hepatic microsomes of rats and mice. The microsomal fraction of livers of Wistar rats and Balb-C mice was separated by ultracentrifugation and $500 \mu \mathrm{L}$ were incubated for 180 minutes with $10 \mu \mathrm{L}$ of racemic HCQ $1000 \mu \mathrm{g} \mathrm{mL}^{-1}$. Two stereospecific analytical methods, high performance liquid chromatography (HPLC) and capillary electrophoresis (CE), were used to separate and quantify the formed metabolites. It was verified that the main formed metabolite is the (-)-(R)-desethyl hydroxychloroquine for both animal species.
\end{abstract}

Uniterms: Hydroxychloroquine. Stereoselective metabolism/in vitro study. High performance liquid chromatography. Capillary electrophoresis.

\begin{abstract}
A hidroxicloroquina (HCQ) é um importante fármaco quiral usado, principalmente, no tratamento de artrite reumatóide, lupus eritematoso sistêmico e malária e cujas propriedades farmacocinéticas e farmacodinâmicas parecem ser estereosseletivas. Em relação às propriedades farmacocinéticas, alguns estudos prévios indicam que a estereosseletividade pode se expressar nos processos de metabolismo, distribuição e excreção e que o metabolismo estereosseletivo parece ser função da espécie estudada. Sendo assim, o metabolismo in vitro da HCQ foi investigado usando microssomas de fígado de ratos e de camundongos. A fração microssômica de fígados de ratos Wistar e de camundongos Balb-C foi isolada por ultracentrifugação e $500 \mu \mathrm{L}$ foram incubados por 180 minutos com $10 \mu \mathrm{L}$ de HCQ racêmica $1000 \mu \mathrm{g} \mathrm{mL}$. Dois métodos analíticos estereoespecíficos, por cromatografia líquida de alta eficiência (HPLC) e eletroforese capilar (CE), foram usados para separar e quantificar os metabólitos formados. Verificou-se que o principal metabólito formado é o $(-)-(R)$-desetilidroxicloroquina para ambas as espécies de animais.
\end{abstract}

Unitermos: Hidroxicloroquina. Metabolismo estereosseletivo/estudo in vitro. Cromatografia líquida de alta eficiência. Eletroforese capilar.

\section{INTRODUCTION}

The hydroxychloroquine (HCQ) has its use approved by FDA (Food and Drug Administration) for the treatment of inflammatory chronic diseases, such as rheumatoid arthritis, systemic lupus erythematosus (SLE) and also as

\footnotetext{
*Correspondence: C. D. Cardoso. Centro de Pesquisa e Análise de Resíduos e Contaminantes-CEPARC, Departamento de Química, Universidade Federal de Santa Catarina, Falta endereço. E-mail: carmem.dicckow@gmail.com
}

antimalarial (Wolf, 2000). It is considered effective and safe, however, 0.5 to $3.5 \%$ of patients submitted to HCQ treatment exhibit retinal lesion. Another adverse effect less intense, but observed with higher frequency is the gastrointestinal toxicity (Hardman et al., 1996; Tanaka et al., 2004).

Its hepatic metabolism generates three active metabolites, desethylchloroquine (DCQ), desethyl-hydroxychloroquine (DHCQ) and bis-desethyl-chloroquine (BDCQ), all of them chiral (Ducharme et al., 1995; Wey et al., 1995) (Figure 1). 
The antiarthritic and antimalarial properties of individual enantiomers of HCQ are unknown, although it has been estimated that, in rats, the $(+)-(S)$-enantiomer of chloroquine (CQ), a drug structurally similar to HCQ, presents higher antimalarial activity than (-)-(R)-CQ (Brocks et al., 1992).

The enantioselective pharmacokinetics and metabolism of HCQ are not totally known as well (Brocks, Mehvar, 2003). The studies respecting kinetic disposition of HCQ have been developed in vivo, from the oral drug administration in human or animals (Brocks et al., 1992; Mclachlan et al., 1993; Iredale et al., 1993; Ducharme et al., 1994; Wainer et al., 1994; Mclachlan et al., 1994; Wey et al., 1995; Ducharme et al., 1995) and have shown the existence of stereoselective processes.

Ducharme et al. (1995) evaluated the enantioselective kinetic disposition of HCQ in healthy humans submitted to a single oral dose of $\mathrm{rac}$-HCQ and observed faster elimination of enantiomer $(+)-(S)-\mathrm{HCQ}$ (proportion $\mathrm{R} / \mathrm{S}>1$ in the plasma), probably due to a faster urinary excretion and/or more accentuated hepatic metabolism of this enantiomer. The metabolites derived from enantiomer $(+)-(S)$ represented $80-90 \%$ of the dose recovered in urine. Metabolites in the blood were not detected.

Other studies were developed in patients with rheumatoid arthritis submitted to single or multiple doses of rac-HCQ (Mclachlan et al., 1993; Mclachlan et al., 1994). McLachlan et al. (1993) have also found, for all patients, higher amounts of (-)-(R)-HCQ, as in the plasma as in the total blood.

Ducharme et al. (1994) have evaluated total blood and plasma of rabbits submitted to multiple doses of racHCQ and from every of the enantiomers separately. On occasion of rac-HCQ administration, higher amount of enantiomer $(+)-(S)$ was found in the plasma, while in the total blood, the concentrations were inverted. Yet for separate enantiomers, in total blood, it was observed higher amount of $(-)-(R)$-HCQ respecting to $(+)-(S)$-HCQ. The observations suggest that the (-)-(R)-HCQ enantiomer is rather concentrated by blood cellular components and once fixed, it would let the enantiomer $(+)-(S)$ more available for the metabolism.

WEY et al. (1995) when studying the stereoselective kinetic disposition of HCQ and their metabolites in rats, obtained, in total blood and in tissues, a proportion $\mathrm{R} / \mathrm{S}>1$ for the enantiomers of HCQ and $<1$ for the enantiomers of metabolites DCQ and DHCQ, indicating that the enantiomer $(+)-(S)-\mathrm{HCQ}$ is rather metabolized or excreted.

In a study with patients bearing SLE, proportions $\mathrm{R} / \mathrm{S}<1$ were obtained for the enantiomers of HCQ in urine and $\mathrm{R} / \mathrm{S}$ in plasma (Brocks et al., 1992).

The data presented above show that the kinetic disposition of HCQ is stereoselective and that such stereoselectivity can express itself in the processes of metabolism, excretion or distribution and depend also on the species employed in the study. Therefore, to study the hepatic metabolism of HCQ separately, it was developed a methodology utilizing the microsomal fraction of livers and analytical methods making use of high performance liquid chromatography (HPLC) and capillary electrophoresis (CE) (Cardoso, Bonato, 2005; Cardoso et al., 2006). Such methodology was, then, employed to study the metabolism of HCQ utilizing microsomal fractions of rats and mice livers.

\section{MATERIAL AND METHODS}

\section{Standard-solutions}

The standards of HCQ and of its metabolites, DCQ, DHCQ and BDCQ employed in the preparation of standard-solutions, were kindly provided by Sanofi-Winthrop Pharmaceuticals (New York, USA). The stock-solutions of HCQ, DCQ and DHCQ were prepared in the concentration of $1000 \mu \mathrm{g} \mathrm{mL}^{-1}$ in methanol:water $(50: 50, \mathrm{v} / \mathrm{v})$. The work solutions, in the concentrations of 5, 10, 20, 50, 100 and $200 \mu \mathrm{g} \mathrm{mL}^{-1}$ were obtained from dilutions, in the same solvent system. All the solutions were stored at $-20{ }^{\circ} \mathrm{C}$ and protected from light.
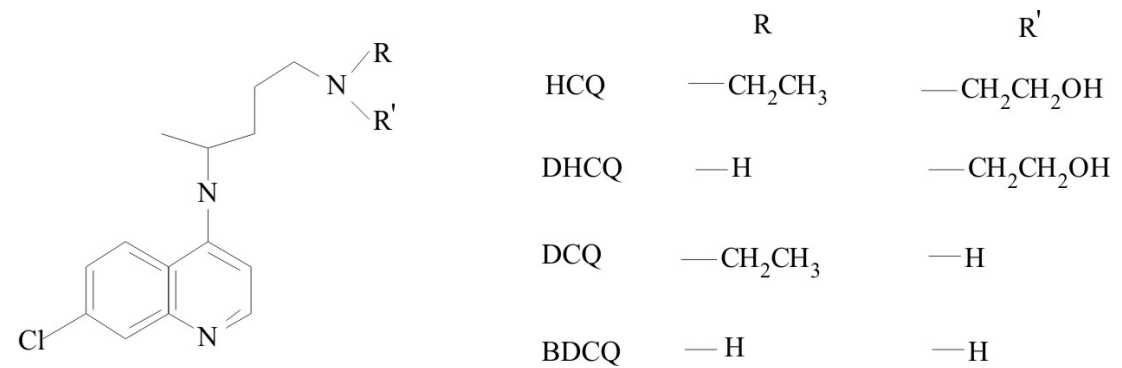

FIGURE 1- HCQ and its metabolites. 


\section{Equipments}

The livers from animals were homogenized with a "Potter" type homogenizer, model MA 039, provided with a water circulator for temperature control, model MA 181 (Marconi, São Paulo, Brazil). The centrifugation steps were developed in a HIMAC CF 15D2 centrifuge (Hitachi, Tokyo, Japan) and in a BECKMAN XL-70 centrifuge (Beckman, Carlsbad, USA). For the protein dosage it was utilized a spectrophotometer SPECTRONIC 20 GENESYS $^{\mathrm{TM}}$ (Spectronic Instruments, New York, USA). The incubations were developed in a heated bath with a Dubnoff stirrer (Marconi, São Paulo, Brazil).

The chromatographic analyses were developed in a Shimadzu chromatograph (Kyoto, Japan) constituted by a pump model LC-10AT VP, Rheodyne injector model 7725 with sampler of $50 \mu \mathrm{L}$, an absorption detector in the visible ultraviolet (UV) model SPD-10A and an integrator model Chromatopac C-R6A.

The electrophoretic analysis of HCQ enantiomers and of its three metabolites was developed in an equipment from Agilent Technologies, model 61600A (Waldbronn, Germany), constituted by an analyzer, an automatic sampler, a detector by diodes arrangement and a system of data acquisition with the software Agilent ChemStation.

A Digimed $\mathrm{pH}$ meter from Digicrom Analitica, model DM-20 (São Paulo, Brazil) was employed to measure the $\mathrm{pH}$ of aqueous solutions. In order to eliminate the air dissolved in the solutions, it was utilized a Thorton ultrasound, model Ultrasonic Cleaner (São Paulo, Brazil).

In the preparation of standard-solutions and electrolytes it was utilized an analytical balance Ohaus Corp. (Pine Brook, USA), model Adventurer.

In the procedure of preparation of samples, a horizontal tubes stirrer (Pachane Ltda., Piracicaba, Brazil), model PA241; a vortex type tubes stirrer (Phoenix Equipamentos Cientificos, Araraquara, Brazil), model AT56 and an Excelsa Baby centrifuge (Fanem, São Paulo, Brazil), model 206 were utilized.

\section{Solvents and reagents}

The salts monobasic and dibasic potassium phosphate were obtained from Merck (Rio de Janeiro, Brazil). The Hepes was obtained from Sigma-Aldrich (Steinheim, Germany). The substances $\beta$-nicotinamide-adenine-dinucleotide phosphate (NADP), glucose-6-phosphate, glucose-6-phosphate dehydrogenase and bovine serum albumin $96 \%$ were obtained from Sigma (St. Louis, USA). The sodium tartrate and the urea were obtained from J. T. Baker (Phillipsburg, USA) and the pentahydrate copper sulfate was obtained from Reagem (Rio de Janeiro, Brazil). The sodium deoxicolate was obtained from Thermo Separation Products (San Jose, USA). The water was purified with the system Milli-Q Plus (Millipore, Bedford, USA).

The solvents (all chromatography grade) utilized in the preparation of samples and in the chromatographic analyses were obtained from EM Science (Gibbstown, USA) (methanol, isopropanol and chloroform); from Mallinckrodt (Paris, USA) (hexane); from Omnisolv (Darmstadt, Germany) (toluene) and from J. T. Baker (Phillipsburg, USA) (acetonitrile). The diethylamine, grade p. a., was obtained from Fluka (St. Gallen, Switzerland).

The reagent tris(hydroxymethyl)-aminomethane (grade p.a.) was obtained from J.T. Baker (Phillipsburg, USA). The hydroxypropyl $\beta$-CD was obtained from Aldrich Chem. Co. (Milwaukee, USA) and the sulfated $\beta-C D$ was obtained from Supelco (Bellefonte, USA).

The solutions used in the equipment of CE were daily filtered, in a MILLEX - HA filter with porosity of $0.45 \mu \mathrm{m}$, obtained from MILLIPORE (Bedford, USA) and taken to ultrasound for degasification.

\section{Animals}

Male and adult Wistar rats and male Balb-C mice were utilized, weighing, respectively, from 180 to $200 \mathrm{~g}$ and from 20 to $30 \mathrm{~g}$. The animals were obtained from Vivarium II of the Faculty of Pharmaceutical Sciences of Ribeirão Preto, classification SPF (Specific Pathogen Free).

\section{Incubation Procedure}

Isolation of microsomal fraction from liver homogenate The animals, acclimatized at $25^{\circ} \mathrm{C}$ with light cycles of 12 hours, were submitted to fasting for one night, before the experiments. At morning, the animals were anesthetized with ether and their livers were submitted to perfusion (Jones, 1987) with sodium chloride at $0.9 \%(\mathrm{~m} / \mathrm{v})$, washed with potassium chloride $0.154 \mathrm{~mol} \mathrm{~L}^{-1}(\mathrm{pH} 7.4)$, triturated and homogenized ( 3 cycles) in a "Potter" type homogenizer. The homogenate was filtered through two layers of gauze to remove residual tissues and the volume was adjusted with the solution of potassium chloride in a way to obtain a suspension at $20 \%(\mathrm{~m} / \mathrm{v})$, approximately. The obtained suspension was centrifuged at 9,000 g for 15 minutes, at $4{ }^{\circ} \mathrm{C}$. The residue was neglected and the supernatant was submitted to ultracentrifugation at $100,000 \mathrm{~g}$ for 60 minutes, at $4{ }^{\circ} \mathrm{C}$. Then, the supernatant was neglected and the resulting 'pellets' were washed and homogenized with buffer solution tris- $\mathrm{HCl} 0.15 \mathrm{~mol} \mathrm{~L}^{-1}$ $(\mathrm{pH}$ 7.6) and again submitted to ultra-centrifugation at 
$100,000 \mathrm{~g}$ for 60 minutes, at $4{ }^{\circ} \mathrm{C}$. The supernatant was neglected and the 'pellets' were homogenized with hepes buffer $1.25 \mathrm{mmol} \mathrm{L}^{-1}$ in $\mathrm{KCl}$ at $1.15 \%$ and stored at $-70{ }^{\circ} \mathrm{C}$ (Von Bahr et al., 1980; Lake, 1987).

The proteins concentration in the microsomal fractions was determined according Cain \& Skilleter (1987).

\section{Optimization of incubation conditions}

All optimization tests (developed in triplicate) were done with isolate rat liver microsomes. Then, the samples were submitted to extraction procedure and analyzed by HPLC (Cardoso, 2005). To achieve the analytical curves, aliquots of $25 \mu \mathrm{L}$ from racemic standard-solutions of metabolites DCQ and DHCQ, in duplicate, were transferred to amber tubes of extraction with grind caps, containing $500 \mu \mathrm{L}$ of diluted white plasma. The concentrations of racemic standard-solutions of metabolites were 2, 5, 10 , $20,50,100$ e $200 \mu \mathrm{g} \mathrm{mL}^{-1}$, resulting in concentrations in the microsomal fractions of 50, 125, 250, 500, 1250, 2500 and $5000 \mathrm{ng} \mathrm{mL}^{-1}$ of every enantiomer.

In the initial procedures of microsomes incubation (adapted from in vitro technologies, 2001), every sample consisted of $500 \mu \mathrm{L}$ of microsomal fraction, $240 \mu \mathrm{L}$ of potassium phosphate $100 \mathrm{mmol} \mathrm{L}^{-1}(\mathrm{pH} 7.4)$ and $10 \mu \mathrm{L}$ of HCQ standard solution. The solution of incubation - NRS (NADPH regenerating system) - consisted of $1.7 \mathrm{mg} \mathrm{mL}^{-1}$ of NADP, $7.8 \mathrm{mg} \mathrm{mL}^{-1}$ of glucose-6-phosphate and 1.5 units/mL of glucose-6-phosphate dehydrogenase on a solution of sodium bicarbonate at $2 \%$. The samples and the NRS solution were maintained in a double boiler for 5 minutes. After this time, $250 \mu \mathrm{L}$ of NRS solution were added to samples in order to start the reaction. At the end, the incubation was interrupted by the addition of $1 \mathrm{~mL}$ of acetonitrile and the samples were submitted to extraction and chromatographic analysis.

The incubation time (30, 90 e 180 minutes), the HCQ racemic concentration $\left(200,500\right.$ and $\left.1000 \mu \mathrm{g} \mathrm{mL}^{-1}\right)$ and the volume of microsomes $(200,300,500$ and $1000 \mu \mathrm{L})$ were optimized.

In order to evaluate the influence of employed anesthetics, the metabolism experiments were also done with samples of microsomes of rats anesthetized with $400 \mu \mathrm{L}$ of intraperitoneal (ip) thiopental. Samples of microsomes of rats treated with the metabolism inducer phenobarbital (Masimirembwa, Hasler, 1994) were also incubated, with the purpose to verify if the metabolism would increase with the use of this inducer. Phenobarbital at $4 \mathrm{mg} \mathrm{mL}^{-1}$, in $\mathrm{NaCl} 0.9 \%$, was injected at a dose of $50 \mathrm{mg} / \mathrm{kg}$ of rat body, for four consecutive days. At the fifth day, the liver microsomal fractions of these rats and of four control-rats (without the inducer administration) were isolated.

\section{Samples preparation and chromatographic and electrophoretic analyses}

For HPLC analysis, the samples were prepared by liquid-liquid extraction with chloroform and analyzed in a Chiralpak AD-RH column, with a hexane:isopropanol $92: 8(\mathrm{v} / \mathrm{v})$ mobile phase with $0.1 \%$ of diethylamine, in a wave length of $343 \mathrm{~nm}$ (Cardoso, Bonato, 2005).

For CE analysis, the samples were prepared by liquidliquid extraction with toluene and analyzed in a capillary of $42 \mathrm{~cm}$ (effective length) x $50 \mu \mathrm{m}$, at $20^{\circ} \mathrm{C}$, with buffer solution tris(hydroxymethyl)aminomethane $100 \mathrm{mmol} \mathrm{L}^{-1}$, $\mathrm{pH} 9.0$, containing $1 \%$ of sulphated $\beta$-cyclodextrin and $30 \mathrm{mmol} \mathrm{L}^{-1}$ of hydroxypropylated $\beta$-cyclodextrin, with detection in $220 \mathrm{~nm}$ (Cardoso et al., 2006).

The concentrations of enantiomers of formed metabolites were determined from the analytical curves also submitted to extraction process.

\section{Metabolism study}

For the study of hepatic metabolism, microsomal fractions isolated from liver of Wistar rats and Balb-C mice were used, with protein concentrations of 30 to $40 \mathrm{mg} \mathrm{mL}^{-1}$. The microsomal fractions isolated from rat liver were incubated with the racemic HCQ $\left(500 \mu \mathrm{g} \mathrm{mL}^{-1}\right.$ of every enantiomer) and also with the isolated enantiomers $\left(420 \mu \mathrm{g} \mathrm{mL}^{-1}\right.$ of (-)-(R)-HCQ and $630 \mu \mathrm{g} \mathrm{mL}^{-1}$ of $(+)-(S)$-HCQ, approximately, obtained by semipreparative separation in HPLC); the determination of enantiomers of formed metabolites was developed by HPLC.

The microsomal fractions isolated from mice were incubated only with racemic HCQ $\left(500 \mu \mathrm{g} \mathrm{mL}^{-1}\right.$ of every enantiomer) and the analyses were developed by HPLC and CE.

\section{RESULTS AND DISCUSSION}

\section{Optimization of incubation conditions}

The choice of the better incubation conditions, i.e., incubation time, racemic HCQ concentration and volume of microsomal fraction, was done utilizing the "Tukey" test, which determines if there is, between the responses from evaluated conditions, a significant difference. Table I shows the average concentrations for every formed enantiomer and the respective coefficient of variation, in the three optimization steps: A - incubation time, B - HCQ and $\mathrm{C}$ concentration - volume of microsomal fraction. In bold are emphasized the conditions that provided better production of metabolites. 
After optimization of incubation conditions, it was also evaluated the influence of employed anesthetic: ethylic ether or thiopental. The proteins dosage in microsomal fractions was of $63.6 \mathrm{mg} \mathrm{mL}^{-1}$ and $59.8 \mathrm{mg} \mathrm{mL}^{-1}$ for the rats anesthetized with ether and thiopental, respectively. Analyzing the obtained results (Table II), an option has been done for the utilization of ethylic ether as anesthetic, as a function of the higher concentration of produced metabolites.

It was also investigated, the in vitro metabolism in liver microsomal fractions of rats pretreated with phenobarbital, an inducer of CYP450 isoforms (Masimirembwa, Hasler, 1994). The investigation has shown only a mild increase in the concentration of metabolites in the microsomal fraction of animals pretreated with phenobarbital (Table II). Despite the increase in the concentration of enantiomers produced, for the majority of metabolites, the option was to work without the inducer, due to the fact that the utilization of it would imply in larger time spent with the experiments. The proteins dosage in both microsomal fractions was of $37.8 \mathrm{mg} \mathrm{mL}^{-1}$.

Table III presents the definitive conditions for the procedure of incubation.

\section{Metabolism of HCQ employing the isolated microsomal fraction of rats liver}

Once established the procedure to be employed in the metabolism process, it was developed a study of racemic HCQ metabolism $\left(1000 \mu \mathrm{g} \mathrm{mL}^{-1}\right)$ and also of isolated enantiomers of the drug $\left(420 \mu \mathrm{g} \mathrm{mL}^{-1}\right.$ of $(-)-(R)$-HCQ and $630 \mu \mathrm{g} \mathrm{mL} \mathrm{m}^{-1}$ of $(+)-(S)-\mathrm{HCQ}$, approximately), which were previously obtained by semipreparative HPLC (Cardoso, Bonato, 2005). The obtained results are described at Table

TABLE I- Average concentrations of every enantiomer produced in the three optimization steps

\begin{tabular}{|c|c|c|c|c|c|c|c|c|}
\hline & \multicolumn{2}{|c|}{$(-)-(R)-\mathrm{DCQ}$} & \multicolumn{2}{|c|}{$(+)-(S)-\mathrm{DCQ}$} & \multicolumn{2}{|c|}{$(-)-(R)-\mathrm{DHCQ}$} & \multicolumn{2}{|c|}{$(+)-(S)-\mathrm{DHCQ}$} \\
\hline & $\begin{array}{c}\text { Conc. } \\
\left(\mathrm{ng} \mathrm{mL}^{-1}\right)\end{array}$ & $R S D$ & $\begin{array}{c}\text { Conc. } \\
\left(\mathrm{ng} \mathrm{mL}^{-1}\right)\end{array}$ & $R S D$ & $\begin{array}{c}\text { Conc. } \\
\left(\mathrm{ng} \mathrm{mL}^{-1}\right)\end{array}$ & $R S D$ & $\begin{array}{c}\text { Conc. } \\
\left(\mathrm{ng} \mathrm{mL}^{-1}\right)\end{array}$ & $R S D$ \\
\hline$A_{30}$ & 387,44 & 2.3 & 148.16 & 11.5 & 505.94 & 2.3 & 179.80 & 7.0 \\
\hline$A_{90}$ & 388,63 & 6.5 & 182.12 & 10.6 & 589.95 & 5.4 & 169.71 & 9.5 \\
\hline $\mathbf{A}_{180}$ & $383,56^{b}$ & 7.4 & $238.93^{a}$ & 8.9 & $739.73^{a}$ & 3.1 & $233.33^{\mathrm{a}}$ & 1.8 \\
\hline$B_{200}$ & 103,59 & 11.48 & $*$ & $*$ & 230.77 & 9.43 & $*$ & $*$ \\
\hline$B_{500}$ & 179,46 & 2.2 & 73.60 & 7.4 & 361.54 & 3.7 & 92.8 & 10.8 \\
\hline $\mathbf{B}_{1000}$ & $378,7^{a}$ & 11.9 & $229.45^{a}$ & 1.1 & $853.85^{a}$ & 10.0 & $330.44^{\mathrm{a}}$ & 7.4 \\
\hline $\mathrm{C}_{200}$ & 438,26 & 12.1 & 402.87 & 7.9 & $695.24^{\mathrm{a}}$ & 12.9 & 554.84 & 6.6 \\
\hline $\mathrm{C}_{300}$ & 386,43 & 12.0 & 274.69 & 8.7 & 662.86 & 8.2 & 322.58 & 13.0 \\
\hline $\mathrm{C}_{500}$ & $327,49^{a}$ & 2.2 & $176.67^{a}$ & 13.3 & $695.24^{\mathrm{a}}$ & 4.1 & $221.50^{a}$ & 13.1 \\
\hline $\mathrm{C}_{1000}$ & 261,43 & 10.9 & 54.12 & 10.0 & 451.43 & 10.8 & 98.92 & 3.8 \\
\hline
\end{tabular}

RSD, relative standard deviation, $n=3$ for every condition, ${ }^{\text {a }}$ significant difference, ${ }^{\text {b }}$ non-significant difference. $*$ Values below quantification limit

TABLE II- Average concentrations of every enantiomer in the experiments evaluating anesthetics and the effect of metabolism inducer

\begin{tabular}{|c|c|c|c|c|c|c|c|c|}
\hline \multirow{2}{*}{ Tests } & \multicolumn{4}{|c|}{$\begin{array}{c}\text { DCQ } \\
(-)-(R)-(+)-(S)-\end{array}$} & \multicolumn{4}{|c|}{$\begin{array}{c}\text { DHCQ } \\
(-)-(R)-(+)-(S)-\end{array}$} \\
\hline & $\begin{array}{l}\text { Conc. } \\
\text { ng } \mathrm{mL}^{-1}\end{array}$ & $R S D$ & $\begin{array}{l}\text { Conc. } \\
\text { ng mL }\end{array}$ & $R S D$ & $\begin{array}{l}\text { Conc. } \\
\text { ng mL }{ }^{-1}\end{array}$ & $R S D$ & $\begin{array}{l}\text { Conc. } \\
\text { ng mL } L^{-1}\end{array}$ & $R S D$ \\
\hline Ethyl Ether & 417.13 & 10.2 & 158.74 & 13.1 & 800.00 & 13.1 & 217.02 & 13.9 \\
\hline Thiopental & 112.91 & 12.6 & 104.16 & 3.6 & 214.81 & 4.9 & 97.87 & 6.2 \\
\hline With inducer & 504.78 & 6.8 & 218.00 & 11.6 & 852.34 & 8.4 & 333.33 & 13.2 \\
\hline Without inducer & 382.41 & 1.8 & 205.37 & 7.33 & 683.95 & 12.6 & 286.11 & 9.4 \\
\hline
\end{tabular}

RSD, relative standard deviation, $n=3$ for every condition. 
TABLE III. Optimized conditions for the in vitro study of metabolism

\begin{tabular}{lc}
\hline Anesthetic & Ethylic ether \\
\hline Volume of microsomal homogenate & $500 \mu \mathrm{L}$ \\
Incubation time & 180 minutes \\
Racemic HCQ concentration & $1000 \mu \mathrm{gL}^{-1}$ \\
Volume of HCQ solution & $10 \mu \mathrm{L}$ \\
\hline
\end{tabular}

IV and the chromatograms representative of incubation are shown at Figure 2. The results show that the enantiomer $(-)-(R)-H C Q$ is preferably metabolized, seeing that the proportions of concentration $[(-)-(R) /(+)-(S)]$ were 2.2 for the DCQ metabolite and 3.3 for the DHCQ metabolite; it was verified also that (-)-(R)-DHCQ is the main formed metabolite. The used method did not allow evaluating the formation of enantiomers of BDCQ metabolite.

In vivo studies developed with rats (Wey et al., 1995) showed higher concentrations of enantiomers $(+)-(S)$ - of metabolites in total blood. Comparing our results with literature data, it was concluded that besides the stereoselective metabolism, other pharmacokinetic processes probably act on occasion of the drug administration.

\section{Metabolism of HCQ employing the isolated microsomal fraction of mice liver}

The same concentrations of racemic HCQ and isolated enantiomers of the drug were used in this experiment. Chromatograms representative of incubation are shown at Figure 2. Table V shows the concentrations for the HCQ metabolites after incubation of racemic mixture and isolated enantiomers. Here the results were also obtained employing methodology developed by HPLC (Cardoso, Bonato, 2005).
For hepatic microsomes of mice, it was also verified that the enantiomer (-)-(R)- HCQ is preferably metabolized, being that the proportions of concentration $[(-)-(R) /$ $(+)-(S)]$ were of 2.0 for the DCQ metabolite and 4.3 for the DHCQ metabolite. (-)-(R)-DHCQ represented also the main formed metabolite.

In the above developed experiments employing HPLC as analytical technique, it was not possible to evaluate the
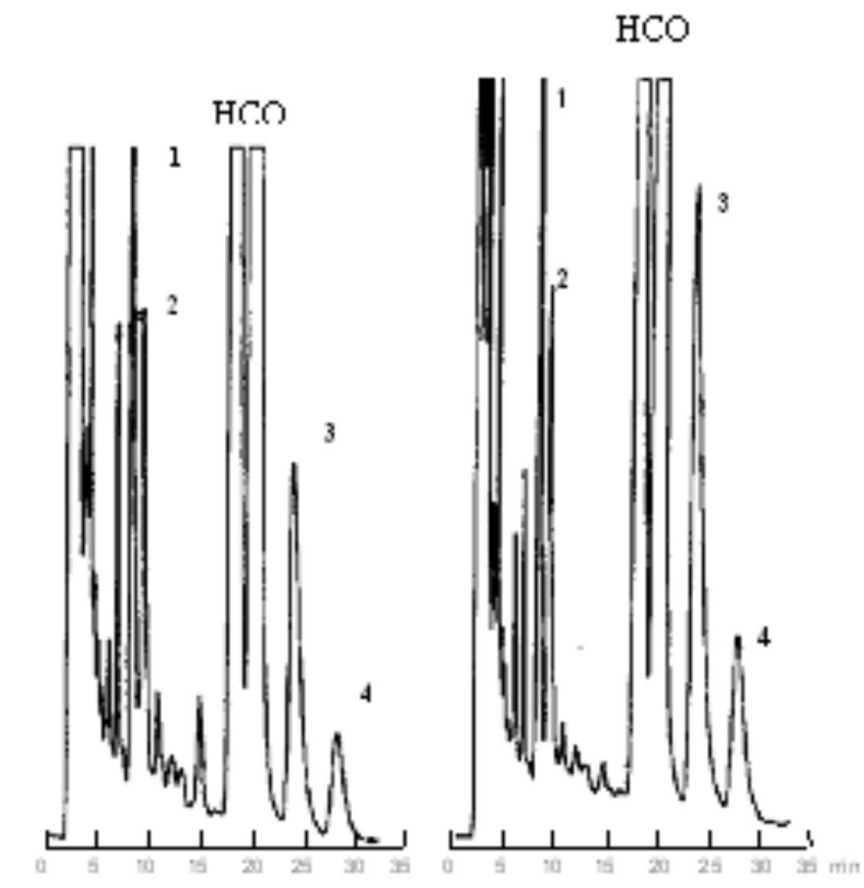

A

B

FIGURE 2- Chromatograms of (A) incubation of microsomal fraction of rats liver with $r a c-\mathrm{HCQ}$ and $(\mathrm{B})$ incubation of microsomal fraction of mice liver. (-)-(R)-DCQ $(\mathbf{1})$ and $(+)-(S)-$ DCQ (2), (-)-(R)-DHCQ (3) and (+)-(S)-DHCQ (4).

TABLE IV- Results of incubation of HCQ with microsomal fraction of rats liver

\begin{tabular}{lccccc}
\hline & Metabolites & DCQ $(-)-(\boldsymbol{R})-$ & $(+)-(\boldsymbol{S})-$ & DHCQ $(-)-(\boldsymbol{R})-$ & $(+)-(\boldsymbol{S})-$ \\
\hline \multirow{2}{*}{ Incubation Rac-HCQ } & Conc. $\left(\mathrm{ng} \mathrm{mL} \mathrm{mL}^{-1}\right)$ & 273.43 & 124.67 & 667.35 & 200.56 \\
& $R S D$ & 3.22 .2 & 10.9 & 9.63 .3 & 5.6 \\
& Proportion R/S & & & 240.04 & 1.5 \\
Incubation (-)-(R)-HCQ & Conc. $\left(\mathrm{ng} \mathrm{mL} \mathrm{mL}^{-1}\right)$ & 127.12 & & & $84.96^{\mathrm{a}}$ \\
& $R S D$ & 10.9 & 61.08 & & 14.5 \\
Incubation (+)-(S)-HCQ & Conc. $\left(\mathrm{ng} \mathrm{mL} \mathrm{mL}^{-1}\right)$ & & 13.2 & & \\
\hline
\end{tabular}

$n=3$ for every incubation; $R S D$, relative standard deviation; ${ }^{\text {a }}$, semiquantitative result, because this value is below of the method quantification limit. 
TABLE V- Results of incubation of HCQ with microsomal fraction of mice live

\begin{tabular}{llllll}
\hline & Metabolites & DCQ $(-)-(R)-$ & $(+)-(S)-$ & DHCQ $(-)-(R)-$ & $(+)-(S)-$ \\
\hline \multirow{2}{*}{ Incubation $r a c-H C Q$} & Conc. $\left(\mathrm{ng} \mathrm{mL} \mathrm{mL}^{-1}\right)$ & 243.12 & 123.81 & 1164.45 & 341.69 \\
& $R S D$ & 2.12 .0 & 4.8 & 2.93 .4 & 1.9 \\
& Proportion R/S & & & 742.25 & \\
Incubation (-)-(R)-HCQ & Conc. $(\mathrm{ng} \mathrm{mL}-1)$ & 170.20 & & 9.2 & 198.70 \\
& $R S D$ & 7.6 & 71.79 & & 4.3 \\
Incubation $(+)-(S)-\mathrm{HCQ}$ & Conc. $\left(\mathrm{ng} \mathrm{mL}^{-1}\right)$ & & 7.2 & & \\
\hline
\end{tabular}

$n=3$ for every incubation; $R S D$, relative standard deviation

formation of BDCQ metabolite. For simultaneous analysis of this and other metabolites, it was employed a method developed by CE (Cardoso et al., 2006). The in vitro study of metabolism was conducted with microsomal liver fractions of mice, with proteins concentration of $30.0 \mathrm{mg} \mathrm{mL}^{-1}$ and incubation with racemic HCQ $\left(1000 \mu \mathrm{g} \mathrm{mL}^{-1}\right)$. A representative electropherogram of incubation is shown at Figure 3 and Table VI shows the concentration of HCQ metabolites after incubation of microsomal fraction with racemic HCQ.

The obtained results show again higher formation of metabolites originated from enantiomer $(-)-(R)-\mathrm{HCQ}$ and that the metabolite BDCQ is formed in lower proportion.

\section{CONCLUSIONS}

The (-)-(R)-HCQ is preferably metabolized by hepatic enzymes of rats and mice, resulting in higher concentrations for all isomers (-)- $(R)$ - of metabolites. The DHCQ metabolite represented the main formed metabolite, in the form of enantiomer (-)-(R)-. However, in vivo pharmacokinetic studies have shown $(R) /(S)<1$ for the HCQ metabolites in human blood or rats blood serum (Wey et al., 1995; Ducharme et al., 1995; Mclachlan et al., 1993, 1994; Brocks et al., 1992, 1994; Emami et al., 1998; Midha et al., 1996). So, considering the experiments described in this work, it could be suggested that another enantioselective process, besides mere metabolism, would be responsible by the enantioselective pharmacokinetics of HCQ. These considerations have

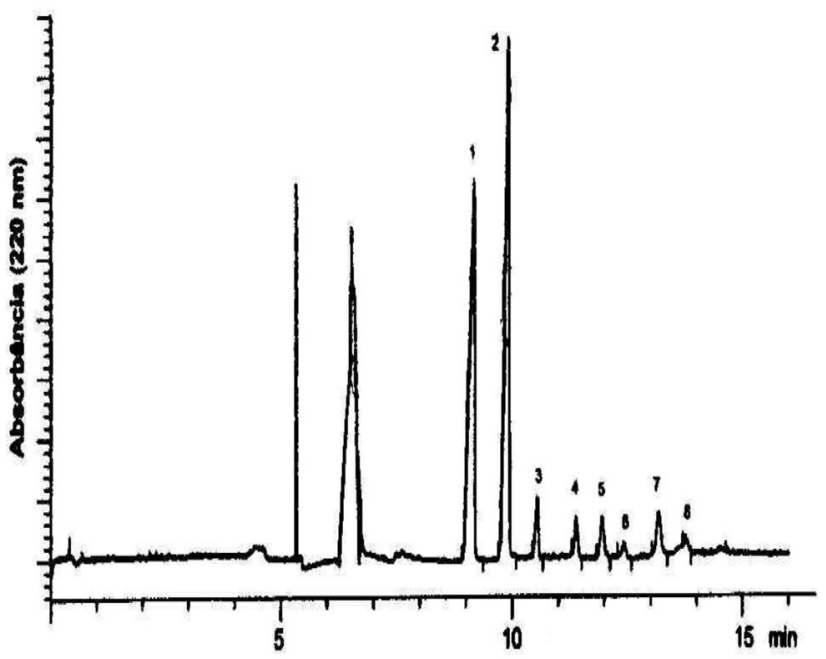

FIGURE 3- Electropherogram of microsomal fraction incubated with rac-HCQ: (1) (-)-(R)-HCQ, (2) (+)-(S)-HCQ, (3) (-)-(R)DHCQ, (4) (+)-(S)-DHCQ, (5) (+)-(S)-DCQ, (6) (-)-(R)-BDCQ, (7) (-)-(R)-DCQ, (8) (+)-(S)-BDCQ

also been reported for the CQ and emphasize the relevance of in vitro studies of metabolism for a complete understanding of the drug kinetic disposition.

\section{ACKNOWLEDGEMENTS}

The authors thank to the 'State of São Paulo Research Foundation' (Fundação de Amparo à Pesquisa do

TABLE VI- Results of HCQ incubation with microsomal fraction of mice liver

\begin{tabular}{lcccccc}
\hline \multirow{2}{*}{ Conc. } & \multicolumn{2}{c}{ DHCQ } & \multicolumn{2}{c}{ DCQ } & \multicolumn{2}{c}{ BDCQ } \\
& $(-)-(\boldsymbol{R})-$ & $(+)-(\boldsymbol{S})-$ & $(-)-(\boldsymbol{R})-$ & $(+)-(\boldsymbol{S})-$ & $(-)-(\boldsymbol{R})-$ & $(+)-(\boldsymbol{S})-$ \\
\hline$(\mathrm{ng} \mathrm{mL}-1)$ & 275.3 & 199.9 & 227.8 & 184.1 & 129.3 & 108.5 \\
$R S D$ & 7.6 & 8.9 & 10.1 & 12.9 & 10.5 & 11.0 \\
\hline
\end{tabular}

$n=3, R S D$, relative standard deviation 
Estado de São Paulo - FAPESP) and the 'National Council of Technological and Scientific Development' (Conselho Nacional de Desenvolvimento Cientifico e Tecnológico $\mathrm{CNPq}$ ) for the financial help and to Catholic University of Pelotas (Universidade Católica de Pelotas - UCPel) for the granted fellowship.

\section{REFERENCES}

BROCKS, D. R.; PASSUTTO, F. M.; JAMALI, F. Analytical and semi-preparative high-performance liquid chromatographic separation and assay of hydroxychloroquine enantiomers. J. Chromatogr., v.581, p.83-92, 1992.

BROCKS, D. R.; MEHVAR, R. Stereoselectivity in the pharmacodynamics and pharmacokinetics of the chiral antimalarial drugs. Clin. Pharmacokinet., v.42, n.15, p.1359-1382, 2003.

CAIN, K.; SKILLETER, D. N. Preparation and use of mitochondria in toxicological research. In: SNELL, K.; MULLOCK, B. (Eds.). Biochemical toxicology - a practical approach. Oxford: IRL PRESS, 1987. cap.9, p.217-253.

CARDOSO, C. D.; BONATO, P. S. Enantioselective analysis of the metabolites of hydroxychloroquine and application to an in vitro metabolic study. J. Pharmac. Biomed. Anal., v.37, p.703-708, 2005.

CARDOSO, C. D.; JABOR, V. P.; BONATO, P. S. Capillary electrophoretic chiral separartion of hydroxychloroquine and its metabolites in the microsomal fraction of liver homogenates. Electrophoresis, v.27, p.1248-1254, 2006.

DUCHARME, J.; WAINER, I.W.; PARENTEAU, H.I.; RODMAN, J.H. Stereoselective distribution of hydroxychloroquine in the rabbit following single and multiple oral doses of the racemate and the separate enantiomers. Chirality, v.6, n.4, p.337-346, 1994.

DUCHARME, J.; FIEGER, H.; DUCHARME, M.P.; KHALIL, S.K.; WAINER, I.W. Enantioselective disposition of hydroxychloroquine after oral of the racemate to healthy subjects. Br. J. Clin. Pharmacol., v.40, n.2, p.127-133, 1995.

EMAMI, J.; PASUTTO, F. M., JAMALI, F. Effect of experimental Diabetes Mellitus and Arthritis on the pharmacokinetics of hydroxychloroquine enantiomers in rats. Pharm. Res., v.15, n.6, p.897-903, 1998.
HARDMAN, J. G.; LIMBIRD, L. E.; MOLINOFF, P. B.; RUDDON, R. W.; GILMAN, A. G. (Eds.). As bases farmacológicas da terapêtica. 9.ed. Rio de Janeiro: McGraw Hill, 1996. p.472.

IN VITRO TECHNOLOGIES. Introductions for using microsomes and S9 fractions. 2001. Available at: $<$ http:// www.invitrotech.com>. Accessed on: 10 may 2002.

IREDALE, J.; FIEGER, H.; WAINER, I.W. Determination of the stereoisomers of hydroxychloroquine and its metabolites in plasma and urine following a single oral administration of racemic hydroychloroquine. Semin. Arthritis Rheum., v.23, n.2-1, p.74-81, 1993.

JONES, R. S. Liver perfusion techniques in toxicology. In: SNELL, K.; MULLOCK, B. (Eds.). Biochemical toxicology - a practical approach. Oxford: IRL PRESS, 1987. cap.2, p.23-55.

LAKE, B. G. Preparation and characterization of microsomal fractions for studies on xenobiotic metabolism. In: SNELL, K.; MULLOCK, B. (Eds.). Biochemical toxicology - a practical approach. Oxford: IRL PRESS, 1987. cap.8, p.183-215.

MASIMIREMBWA, C. M.; HASLER, J. A. Characterization of praziquantel metabolism by rat liver microsomes using cytochrome P450 inhibitors. Biochem. Pharmacol., v.48, n.9, p.1779-1783, 1994.

MIDHA, K. K.; HUBBARD, J. W.; RAWSON, M. J.; McKAY, G.; SCHWEDE, R. The roles of stereochemistry and partial areas in a parallel design study to assess the bioequivalence of two formulations of hydroxychloroquine: a drug with a very long half life. Eur. J. Pharm. Sci., v.4, p.283-292, 1996.

McLACHLAN, A.J.; TETT, S.E.; CUTLER, D.J.; DAY, R.O. Disposition of the enantiomers of hydroxychloroquine in patients with rheumatoid arthritis following multiple doses of the racemate. Br. J. Clin. Pharmacol., v.36, n.1, p.78-81, 1993.

McLACHLAN, A.J.; TETT, S.E.; CUTLER, D.J.; DAY, R.O. Disposition and absorption of hydroxychloroquine enantiomers following a single dose of the racemate. Chirality, v.6, n.4, p.360-364, 1994.

TANAKA, E.; TANIGUCHI, A.; URANO, W.; YAMANAKA, H.; KAMATANI, N. Pharmacogenetics of diseasemodifying anti-rheumatic drugs. Best Pract. Res., Clin. Rheumatol., v.18, n.2, p.233-247, 2004. 
VON BAHR, C.; GROTH, C. G.; JANSSON, H.; LUNDGREN, G.; LIND, M.; GLAUMANN, D. H. Drug metabolism in human liver in vitro: establishment of a human liver bank. Clin. Pharmacol. Ther., v.27, n.6, p.711-725, 1980.

WAINER, I. W.; CHEN, J. C.; PARENTEAU, H.; ABDULLAH, S.; DUCHARME, J., FIEGER, H.; IREDALE, J.; Distributions of the enantiomers of hydroxychloroquine and its metabolites in ocular tissues of the rabbit after oral administration of racemic-hydroxychloroquine. Chirality, v.6, n.4, p.347-354, 1994.
WEY, Y.; NYGARD, G.A.; ELLERTSON, S.L.; KHALIL, S.K. Stereoselective disposition of hydroxychloroquine and its metabolites in rats. Chirality, v.7, n.8, p.598-604, 1995.

WOLF, R.; WOLF, D.; RUOCCO, V. Antimalarials: unapproved uses or indications. Clin. Dermatol., v.18, p.17-35, 2000.

Received for publication on $28^{\text {th }}$ March 2008. Accepted for publication on $11^{\text {th }}$ May 2009. 
